Марина Миколаєнко

ORCID: orcid: 0000-0001-6495-8689

DOI 10.31558/1815-3070.2021.42.6

УДК 659.1:81-49.2

\title{
АДРЕСАЦІЯ ЯК МАНІПУЛЯТИВНА ТЕХНОЛОГІЯ В РЕКЛАМНІЙ ГАЛУЗІ
}

У статті розглянуто адресацію як маніпулятивну технологію у текстах рекламних повідомлень (на основі італійських рекламних слоганів). Розкрито історичні аспекти формування маніпулятивних стратегій, спрямованих на адресата, з метою популяризації товарів та послуг та подальшого налагодження масового виробництва товарів. Охарактеризовано постать Е. Бернейза як основоположника використання маніпулятивних технологій з метою збільшення попиту на певні товари та послуги у післявоєнні роки.Також у статті на прикладах розглянуто мовні маніпулятивні технології, які використовуються сьогодні в рекламних текстах італійською мовою.

Ключові слова: адресат, мовні маніпуляиії, маніпулятивні технологї̈ та стратегії, реклама, рекламний текст, слоган.

Постановка наукової проблеми. Значне місце у галузі комунікації відводиться рекламним текстам, основна функція яких полягає у спонуканні споживачів до певних дій, скажімо, придбати товар, який рекламується, використання різноманітних послуг тощо. За допомогою таких текстів рекламодавці тримають увагу споживачів та несвідомо змушують запам'ятовувати слогани, які потім часто легко відтворити в голові.

Велика конкурентність на українському та світовому ринку спричинила використання ряду маніпулятивних технологій , зокрема мовних, у рекламних текстах 3 метою підвищення продажів товарів та послуг. Адресація $є$ одним 3 найбільш ефективних способів впливу тому, що завдяки їй рекламодавці та підприємства можуть контактувати безпосередньо з цільовою аудиторією.

Актуальність дослідження зумовлена тим, що сьогодні вплив реклами на аудиторію безумовний, адже її суспільна роль полягає у формуванні ціннісних понять громадян. Реклама стала інструментом формування національної свідомості. Завдяки рекламі можна впливати на споживачів, пропонуючи нові товари в останніх тенденціях моди. Для підвищення продажів та збільшення популярності рекламодавці часто вдаються до маніпуляції в бік цільової аудиторії.

Аналіз досліджень цієї проблеми. Багато науковців досліджували різні аспекти, пов'язані з адресатом, у межах рекламного дискурсу. Питання встановлення категорій адресата окреслено у наукових працях Н. Арутюнової, Ф. Бацевича, Г. Почепцова, О. Селіванової. Поетика адресата стала об'єктом дослідження М. Бахтіна, Ю. Лотмана, Г. Степанова. У комунікативно-прагматичному аспекті питання адресації та адресата досліджували Т. Винокур, С. Петрова. Р. Варт розкриває сучасне бачення поняття адресат.

Вітчизняні дослідники розкривали питання адресації, що стосувалися лінгвістичних та семантичних характеристик: М. Скаб, О. Голубовська. 
Мета дослідження полягає у визначенні характеристик адресації як маніпулятивної технології в рекламі, окресленні історичних аспектів, пов'язаних із адресацією, зокрема впливу фройдизму на формування цільової аудиторії.

Відповідно до мети поставлено такі завдання: визначити поняття адресата та адресаиіï; окреслити роль Е. Бернейза у розвитку рекламних повідомлень та маніпулятивних технік, спрямованих на цільову аудиторію споживачів, та розглянути адресацію як маніпулятивну технологію на прикладах італійських рекламних слоганів.

Об’єктом дослідження є вибірка італомовних рекламних текстів.

Предметом дослідження є маніпулятивні принципи та стратегії, використані в італомовних рекламних текстах.

Опис фактичного матеріалу та методів, застосованих у процесі аналізу. Матеріалом для дослідження слугувала вибірка рекламних слоганів відомих світових компаній та брендів, які популяризують свою продукцію на території Італії та всього світу.

Відповідно до поставлених завдань статті застосовано комплекс дослідницьких методів, що дали змогу цілісно та різновимірно окреслити роль адресата у рекламному дискурсі, маніпулятивні принципи та стратегіï, застосовані у текстах відносно до адресата. Використано теоретичні методи: аналізу та синтезу, узагальнення, індукції і дедукції - для виявлення маніпулятивних особливостей при перекладі слоганів з італійської мови на українську; системний метод - для встановлення зв'язків між перекладами рекламних слоганів різними мови; історичний метод - для дослідження розвитку маніпулятивних стратегій, застосованих у текстах рекламних повідомлень 3 метою реагування споживачів; метод систематизації - для визначення характерних маніпулятивних ознак у лексиці італійських рекламних слоганів. У дослідженні застосовано також емпіричні методи: порівняння - для виявлення спільних та відмінних рис між слоганом-оригіналом та слоганом-перекладом; описовий - для уточнення фактичної інформації у статті.

Наукова новизна статті полягає у тому, що в ній проведено комплексний аналіз адресації як маніпулятивної стратегії, застосованої у італійських рекламних повідомленнях; з'ясовано вплив фройдизму на розвиток та становлення адресації як технології маніпуляції; виділено спільні та диференційні мовні засоби, що використовуються в побудові рекламних текстів італійською та українською мовами.

Теоретичну цінність отриманих результатів вбачаємо у комплексному аналізі адресації як маніпулятивної стратегії у рекламному дискурсі.

Практична цінність роботи полягає у можливості застосування його матеріалів у курсах з мовознавства, порівняльної лексикології та стилістики під час вивчення італійської мови у вищій школі. Також, отримані результати можуть бути використані у курсах журналістики та реклами, з огляду на розкриття ряду історичних матеріалів стосовно зародження рекламних текстів. Окрім того, матеріали роботи можуть бути використані на практиці філологів та перекладачів 3 італійської мови. 
Виклад основного матеріалу й обгрунтування результатів дослідження. У сучасних лінгвістичних дослідженнях зустрічаємо різні терміни на позначення адресата: аудиторія, глядач, інтерактант, інтерпретатор, одержувач, партнер, публіка, реципієнт, співрозмовник, слухач, читач та інші. Дослідник Ф. Бацевич у праці «Основи комунікативної лінгвістики» подає таке визначення поняття: «адресат - особа, яка сприймає повідомлення і у відповідності зі своїми когнітивними стратегіями і конкретними конситуативними умовами інтерпретує повідомлення адресата» (Бацевич 2004: 173).

I. Кириченко трактує визначення адресата так: «Адресат - це особа, яка сприймає скероване ій через різні інформаційні канали повідомлення, крізь призму власного «я», досвіду, культурної картини світу, середовища, соціального стану, приналежності до певної культури, та схильна інтерпретувати отриману інформацію» (Кириченко 2006: 192).

М. Венгринюк виділяє наступні типи адресата:

- за спрямуванням (зовнішні та внутрішні);

- обсягом (одиничні та масові);

- за статусом (приватні, публічні, соціальні) (Венгринюк 2006: 20).

Дослідниця О. Воробйова вводить термін адресованість. Учена вважає, що адресованість $\epsilon$ необхідною рисою для комунікації загалом, яку розглядають як семантичну складову повідомлення. О. Воробйова розділяє поняття адресатності та адресованості. Адресованість співвідноситься з семантичним сприйняттям повідомлення для виявлення можливого адресата мовлення, що опредмечений у самому тексті. Адресатність асоціюється з міжкультурним складником семантики текстового повідомлення, завдяки якому втілюються різноманітні елементи суб'єкта мовлення (Воробйова 1993: 115).

О. Селіванова вважає, що «адресатність - це текстова категорія, представлена вбудованою в текст програмою його адресованості гіпотетичному читачеві, яка повинна сприяти оптимізації розуміння й інтерпретації тексту реальним читачем» (Селіванова 2008: 18). На думку дослідниці, адресатність можна вважати текстово-дискурсивною категорією, яка зображує розщеплення безпосередньо адресата на отримувача повідомлення, адресата-функцію та фігуру адресата (сприйняття адресата реальним читачем).

Зважаючи на поняття адресат, адресованість та адресатність, ми говоримо, що адресація в рекламному дискурсі - це процес передачі споживачу основної інформації про товар або послуги, шляхом виокремлення певних якостей товару та його характеристик.

У теорії масових комунікацій та філологічних науках поняття «адресат» набуло термінологічного характеру, воно часто використовується як синонім до «цільової аудиторії». Термін досліджується за різними принципами, спрямованими на гендер, соціальний статус, національність, рід діяльності людини та інше. Для окреслення певної цільової аудиторії піарники використовують певні групи рис та характеристик: демографічних, соціальних, професійних, ідеологічних і т. д., на основі цих груп створюється певна типологія засобів масової комунікації. Для встановлення типу 3МІ вистачає однієї чи двох характерних ознак, 
скажімо жіночий журнал або ліберальна преса. Для створення детального портрету цільвої аудиторії треба вивчити весь набір соціальних ролей для потенційного споживача (Каминская 2009: 114). Так ми можемо бачити, як образ адресата (а саме цільовою аудиторією є жінки, якщо мова іде про жіночий журнал, або прихильників ліберальної партії, якщо ми говоримо про ліберальну пресу) вже вкладено в саму назву товару і спрощує самим споживачам у виборі товару.

Активне дослідження цільової аудиторії та адресата рекламного повідомлення почалося на початку XX ст. у Сполучених Штатах, де відомий спеціаліст у галузі зв'язків із громадськістю, Е. Бернейз використав ідеї свого дядька 3. Фройда про підсвідоме та використав їх для маніпуляції масами. Йому вдалося вперше показати американським корпораціям, як вони можуть змусити людей хотіти речі, яких вони не потребують, пов'язуючи масове виробництво товарів із підсвідомими бажаннями (Ewen 2008: 150). Так виникла нова маркетингова ідея про те, як контролювати маси людей, задовольняючи їх потреби та роблячи їх щасливими.

На початку XX ст. США стали потужним центром масового промислового виробництва з центрами у найбільших містах. Е. Бернейз намагався знайти нові дієві способи, які б допомогли контролювати і змінювати почуття мас. Саме тому він звернувся до робіт свого дядька, 3. Фройда. Він прочитав «Введення в психоаналіз» і був вражений прихованими ірраціональними силами всередині людини. Тоді він задумався над тим, як можна заробити гроші, маніпулюючи підсвідомістю. Він зрозумів, що існує багато факторів, які впливають на ірраціональні емоції.

Е. Бернейз почав експериментувати зі знаннями про широкі маси. Суть його першого експерименту зводилася до того, аби змусити жінок палити, а в той час існувало табу на жінок, які палять, адже цигарка вважалася символом чоловічої сексуальної сили. Під час пасхального параду Е. Бернейз умовив групу молодих жінок із заможних родин вийти на площу та запалити, також він повідомив пресі про протест та підпалення «факелів свободи». Новина розлетілася світом, продаж цигарок зріс і куріння жінками стало соціальним явищем. Е. Бернейз створив ідею, що коли жінка палить, це робить їі більш сильною та незалежною. Ця ідея існує досі. Ця подія довела, що можна змусити людей вести себе ірраціонально, якщо об'єднати товари із ірраціональними бажаннями та почуттями людей (Папкова 2010: 53).

Хоча після війни Сполучені Штати вийшли багатими і сильними, великі корпорації боялись надмірного виробництва, адже якщо люди матимуть достатньо речей, вони перестануть їх купувати. До того моменту мільйони товарів продавали через необхідність, вони просувалися з точки зору функціональності та довговічності, а реклама показувала практичну цінність товарів. Корпорації прагнули, щоб люди купували не тільки те, що потрібно, але і те, що бажано, бажання протиставили необхідності.

Е. Бернейз став у центрі створення нового менталітету, він створив новий тип споживачів та почав розробляти методику масового переконання споживачів, яка існує і сьогодні.

Е. Бернейз розміщував фото відомих кінозірок на обкладинки журналів, на прем'єрах фільмів він одягав зірок в одяг інших фірм, які він представляв. Він 
першим порекомендував фірмам продавати автомобілі, як символ чоловічої сексуальності. Також Бернейз влаштовував покази мод в універмагах, де відомі зірки переконували простих людей, що, купуючи одяг, можна показати свій внутрішній світ іншим людям (Кузнецов 2017: 17).

Праці 3. Фройда про позасвідоме стали основою для кращого розуміння споживачів та заклали підгрунтя для створення маніпулятивних технік у рекламних повідомленнях.

Дослідники М. Троян та М. Хижняк вважають, що «мовне маніпулювання це відбір і використання таких засобів мови, за допомогою яких можна впливати на адресата» (Троян, Хижняк 2011: 200). Така маніпуляція передбачає сильний вплив на адресата, який сприймає подібну інформацію об'єктивно. Інформація репрезентується у такий спосіб, що на її основі адресат «самостійно» робить певні висновки та в подальшому приймає рішення придбати товар.

Будь-яке слово так чи інакше впливає на людину. Мовленнєвий вплив за допомогою мови здатен змінити думку адресата у необхідному напрямку. Його можна втілювати за допомогою прохання, примусу, наказу, навіювання чи вмовляння (Рудик 2008).

Маніпулятивні технології часто застосовуються у рекламних повідомленнях, зважаючи на загальні відомості про адресата, тобто гендерні, вікові, соціальні особливості, а також релігійну приналежность. Якщо говорити про італійську рекламу, то нерідко можна побачити зображення жінки в образі Мадонни, а чоловіка - в образі Давида. Жінка постає вишуканою, граційною, пластичною, вона може елегантно повернути голову чи опустити очі. Така жінка $є$ справжнім ідеалом. Якщо говорити про молодих незаміжніх жінок, то образ стає дещо приземленішим та схожим на реальність. Вона - стильна, елегантна, впевнена в собі та приваблива, натомість знає, як заробити гроші, піклується про свою родину. Прикладами є слогани: L'Oreal - Perché io valgo (L'Oreal - Tому щзо я того варma), Karinzia - Profumo d'intesa (Karinzia - Запах розуміння).

Італійський чоловік на противагу жінкиам постає впевненим мачо, до нього прикуті всі погляди протилежної статі. Він сильний, красивий, з особливою уважністю слідкує за своїм зовнішнім виглядом, любить свою обраницю, але не нехтує увагою інших відносно себе. Італійський чоловік в рекламі - це не прояв нарцисизму, це прояв сили та мужності, що стає відголоском часів Великої римської імперії. Мужність та сила зображена у таких слоганах: Lamette Gilette - Il meglio di un иото (Lamette Gilette - Кращий серед чоловіків), Axe - L'istinto di un иото (Ахе - Інстинкт справжнього чоловіка), Denim - Per l'uото che non deve chiedere - mai! (Denim - Для чоловіка, якого не треба просити - ніколи»), Del Monte - L'uomo Del Monte ha detto sì (Del Monte - Дель Монте сказав TAK).

Подібні рекламні тексти розкривають жінок та чоловіків з їхніх найкращих сторін, а такими їх роблять конкретні послуги та товари. Подібна інформація адресується споживачам, які також захочуть мати ті речі, якими володіють заможні, успішні та красиві, тому точно придбають їх собі, аби підкреслити свою індивідуальність.

Ще одним видом маніпуляції в італійській рекламі $є$ опис товару як найкращого у своєму роді, адже італійці - нащадки римлян і вони звикли до найліп- 
шого. Прикладами можна навести слогани: Amaro Lucano - Voglio il meglio, Acqua Levissima - Altissima, purissima, Levissima!, Mulino Bianco Barilla - Chi mangia sano trova la natura.

Також рекламні тексти часто будуються на основі питання та відповіді, що слідує одразу. Це також є маніпулятивною стратегією та значно спрощує вибір покупців, адже підсвідомо вони уже мають відповідь на запитання, яке цікавить не лише конкретну людину, а багатьох. Серед великої кількості італійських слоганів можна виділити такі: Granbiscotto, prosciutto cotto - "Crudo o cotto? Granbiscotto" (Сирий чи варений? Granbiscotto), Ammorbidente Perlana - "È nuovo?" "No, lavato con Perlana" (Ammorbidente Perlana - Hoвa? Hi, nросто випрана з Perlana), Pic siringhe - "Fatto? Già fatto? E' pic!" (Pic siringhe - Готово? Вже зроблено! Фото), Amaro Lucano - "Cosa vuoi di più dalla vita? Un Lucano!" (Aтано Lисапо - Чого найбільше ти хочеш від життя? Lисапо!), Urrà - "Io non ho mai provato Urrà... E tu hai mai provato Urrà?" (Urrà - Я ніколи не пробував Urrà... А ви пробували?).

$€$ такі рекламні тексти, у яких можна побачити явище, коли задля покупця приноситься жертва у тексті безпосередньо. Така маніпулятивна стратегія створюється для того, аби показати цінність та значущість адресата для виробника. Прикладом можна навести рекламний текст Tuborg - “Farei tutto per tu", який перекладемо як «Я все б зробив за тебе». Виходячи із тексту можемо стверджувати, що адресат набуває значущості, бо для кого робити продукт, як не для споживача.

Вплив адресації як маніпулятивної технології має як позитивні, так і негативні ознаки. 3 одного боку, споживачі купують товар, покращують умови свого життя завдяки певним товарам, виглядають красивішими, та з іншого боку, є низка негативних характеристик маніпуляцій, коли люди женуться за брендами та купують непотрібні й дорогі речі. Створюючи подібний до чийогось імідж, люди втрачають власну автентичність.

У рекламних слоганах можемо спостерігати використання вищого та найвищого ступенів порівняння прикметників. Така маніпулятивна стратегія застосовується для того, аби показати, що товар чи послуга хорошої якості на ринку та гідний називатися найкращим серед ряду схожих за ознаками та властивостями товарів. А кожна людина хоче отримувати найкращий товар у будь-якій ціновій категорії.

Прикладом є вже згаданий вище слоган мінеральної води в Італії: Асqua Levissima - "Altissima, purissima, Levissima!". Те саме явище спостерігаємо в рекламі пива Carlsberg - "Probabilmente la migliore birra del mondo" (Напевно, найкраще пиво у світі), віскі Chivas Regal - "Il più regale dei whisky" (Найкрасивіший з віскі), вина Zonin - "I migliori anni della nostra vite" (Найкращі роки нашого життя) або слоган макаронних виробів Mulino Bianco Barilla - "Mangia sano e vivi meglio" (Їжте здорову їжу і живіть краще). Використання вищого та найвищого ступеня порівняння - часте явище в італійській рекламі, адже італійці як нащадки Великої Римської імперії не можуть постачати на світовий ринок товари 3 поганою якістю чи гірші за товари подібного характеру. 
Також ми можемо часто спостерігати пряме спонукання у рекламному тексті, що також слугує мовною маніпуляцією. Автор наче вказує споживачу, що потрібно придбати товар чи скористатися певними послугами, що у тексті проявляється знаками оклику та конкретними дієсловами у наказовому способі, тобто, «дій», «купуй», «спробуй», «отримай», «відчуй». Прикладом можна навести слоган шоколадних батончиків Kit Kat - "Fai un break, spezza con Kit Kat!" (Kit Kat-Зроби паузу, з '̈̈ж Kit Kat!).

У цьому прикладі є спонукання "Fai un break", тобто «зроби перерву». Окрім того, можна спостерігати знак оклику в усіх подібних рекламних текстах, це додає особливої впевненості у товарі і адресат такого повідомлення може довіряти якості товару.

Ще одним прикладом спонукання у рекламі є слоган Coop - "La Coop sei tu!" (Соop - Tu i $є$ Coоp!) В ньому можна простежити ті самі ознаки.

Висновки та перспективи дослідження. У статті було визначено характерні ролі адресації як маніпулятивної технології у галузі реклами, також було окреслено поняття адресат, адресація.

Окрім того, розкрито історичні аспекти, пов'язані з адресацією, зокрема впливу фройдизму на формування цільової аудиторії. Також було розкрито постать Е. Бернейз, який винайшов ідею пов'язування людських емоцій та несвідомого з товарами та послугами, за допомогою ідей свого дядька, 3. Фройда, якому вдалося змінити американську культуру споживання на культуру бажання, а також створити новий менталітет, який виголошував, що індивідуальні бажання повинні затуманювати потреби.

У статті було розглянуто маніпулятивні стратегії та техніки на прикладах рекламних текстів італійською мовою. Маніпулятивні техніки стосовно адресата розглядалися на основі італійської культури, традицій та способу життя. Серед мовних маніпуляцій було виокремлено використання найвищого ступеня порівняння, запитання та відповіді в одному слогані, опису товарів таким чином, аби адресат відчував потребу в них та неможливість користування іншими.

Стаття може бути використана філологами, журналістами та піарниками для подальших досліджень адресата та маніпулятивних стратегій, які можуть виражатися в адресації.

\section{Література}

1. Бацевич Ф. Основи комунікативної лінгвістики. К.: Академія, 2004. 342 с.

[Batsevych F. Osnovy komunikatyvnoyi linhvistyky. K.: Akademiya, 2004. 342 s.]

2. Венгринюк М. Адресат у художньому тексті (на матеріалі української прози XX століття) : автореф. дис. ... канд. філол. наук : спец. 10.02.01 «Українська мова», Івано-Франківськ, 2006. 20 с.

[Venhrynyuk M. Adresat u khudozhn'omu teksti (na materiali ukrayins'koyi prozy XX stolittya) : avtoref. dys.... kand. filol. nauk: spets. 10.02 .01 «Ukrayins'ka mova», IvanoFrankivs'k, 2006. 20 s.]

3. Воробьева О. Текстовые категории и фактор адресата. К.: Вища школа, 1993.

[Vorob’yeva O. Tekstovyye kategorii i faktor adresata. K.: Vishcha shkola, 1993.] 
4. Кириченко I. Місце терміна «адресат» у системі термінів комунікативної лінгвістики [B:] Вісник Наи. ун-ту «Львівська політехніка». Серія «Проблеми украӥнської термінолоziï» 559, 2006: 192-194.

[Kyrychenko I. Mistse termina «adresat» u systemi terminiv komunikatyvnoi linhvistyky [B:] Visnyk Nats. un-tu «Lvivska politekhnika». Seriia «Problemy ukrainskoi terminolohii» 559, 2006: 192-194.]

5. Кузнецов П. Связи с общественностью для бизнеса: практические приёмы. «Дашков и К», 2017. $296 \mathrm{c}$.

[Kuznetsov P. Svyazi s obshchestvennost'yu dlya biznesa: prakticheskiye priyëmy. «Dashkov i K», 2017. 296 s.]

6. Папкова О. В. Связи с общественностью. М.: Академия, 2010. 112 с.

[Papkova O. V. Svyazi s obshchestvennost'yu. M.: Akademiya, 2010. 112 s.]

7. Рудик I., Муратова I. Мовні знаки як інструменти маніпуляції й вербальної агресії в політичному дискурсі [B:] Вісник Житомирського державного університету. Філологічні науки 40, 2008: 186-189.

[Rudyk I., Muratova I. Movni znaky yak instrumenty manipulyatsiyi y verbal'noyi ahresiyi v politychnomu dyskursi [V:] Visnyk Zhytomyrs'koho derzhavnoho universytetu. Filolohichni nauky 40, 2008: 186-189.]

8. Селіванова О. Олександрівна. Сучасна лінгвістика: напрями та проблеми : підручник, Полтава: Довкілля-К, 2008. 711 с.

[Selivanova O. Oleksandrivna. Suchasna linhvistyka: napryamy ta problem: pidruchnyk, Poltava: Dovkillya-K, 2008. 711 s.]

9. Троян М., Хижняк М. Міжнародна стратегія економічного розвитку регіону [B:] Матеріали доповідей II Міжнародної науково-практичної конференциї: Суми: СумДУ, 2011. С. 199201.

[Troyan M., Khyzhnyak M. Mizhnarodna stratehiya ekonomichnoho rozvytku rehionu [V:] Materialy dopovidey II Mizhnarodnoyi naukovo-praktychnoyi konferentsiyi. Sumy : SumDU, 2011. S. 199-201.]

10. Ewen S. «Visiting Edward Bernays» [In:] PR! A Social History Of Spin. Basic Books. Archived from the original on September 5, 2008.

\section{ADDRESSING AS A MANIPULATIVE TECHNOLOGY IN THE ADVERTISING INDUSTRY \\ Maryna Mykolaienko \\ Department of Foreign Philology, Kyiv National University of Culture and Arts, Kyiv. Ukraine.}

Abstract

Background: Today, the main function of advertising is to encourage consumers to take certain actions, such as buying goods, using services. With such texts, advertisers hold the attention of the recipients and unconsciously force them to memorize slogans, which are then often easily reproduced through rhymes, similar-sounding words, etc. High competition in the world market has led to the use of a number of manipulative technologies, including language, in advertising texts in order to increase sales of goods and services. Addressing is one of the most effective.

Purpose: The purpose of the study is to determine the characteristics of the role of addressing as a manipulative technology in advertising, to outline the historical aspects related to addressing, in particular the influence of Freudianism on the formation of the target audience.

Results: Addressing is one of the most effective ways to influence the fact that it allows advertisers and businesses to communicate directly with the target audience. Addressing is one of the most effective ways to influence because it allows advertisers and businesses to communicate directly with their target audience.

Manipulative techniques are often used in advertising texts that are addressed to a group of buyers. They are built into the text of the advertisement in such a way that the buyer himself wants to buy the product in order to have some unique, special thing that is the best among such. 
Discussion: The article considers addressing as a manipulative technology in the texts of advertising messages, reveals the historical aspects of the formation of manipulative strategies aimed at the recipient. Also in the article on examples the manipulative language technologies are considered.

Key words: addressee, language manipulations, manipulative technologies and strategies, advertising, advertising text, slogan.

\section{Vitae}

Maryna Mykolaienko, aspirant, department of Foreign Philology, Kyiv National University of Culture and Arts. Her areas of research interests include philology, translation, cognitive linguistics, contrastive linguistics, functional linguistics.

Correspondence: maryna-mykolaenko@ukr.net

Надійшла до редакції 04 вересня 2021 року Рекомендована до друку 20 жовтня 2021 року 